Gut, 1986, 27, 1069-1072

\title{
Liver and biliary
}

\section{Enhancement of antibody production to hepatitis B surface antigen by anti-idiotypic antibody}

\author{
S KAKUMU, K MURASE, A TSUBOUCHI, K YOSHIOKA, AND N SAKAMOTO \\ From the Third Department of Medicine, Nagoya University School of Medicine, Nagoya, Japan
}

SUMMARY Studies were undertaken to determine whether anti-idiotypic antibody (anti-Id) against antibody to hepatitis B surface antigen (anti-HBs) could modulate in vitro anti-HBs production by human peripheral blood mononuclear cells stimulated with pokeweed mitogen. Peripheral blood mononuclear cells from patients positive for serum anti-HBs produced significantly increased amounts of anti-HBs by the addition of IgG fraction of anti-anti-HBs as well as purified HBsAg in a soluble form when compared to those in cultures with pokeweed mitogen alone. $\mathrm{F}\left(\mathrm{ab}^{\prime}\right)_{2}$ but not $\mathrm{Fc}$ fragments of anti-anti-HBs significantly enhanced anti-HBs levels in cultures. Anti-anti-HBs or HBsAg alone, however, did not induce anti-HBs production. Anti-HBs production was not observed by the additions of these additives when peripheral blood mononuclear cells from chronic $\mathrm{HBsAg}$ carriers and control individuals were used. These findings indicate that anti-Id modulates the immune response to $\mathrm{HBs} \mathrm{Ag}$.

Jerne $^{1}$ proposed that the immune response to an antigen can be regulated by a series of idiotype (Id)-anti-Id reactions. Ids, which are located on or close to the antigenbinding site of both antibody molecules and antigen receptors on lymphocytes, are components of this network. Anti-Id can limit the immune response to an antigen ${ }^{2}$ or, enhance the immune response to it. $^{45}$

Kennedy $e t a t^{6}$ found that prior injection of antibodies to the idiotype of antibody to hepatitis B surface antigen (anti-HBs) into mice markedly increased the number of spleen cells secreting immunoglobulin $\mathrm{M}(\operatorname{IgM})$ anti-HBs when the mice were subsequently inoculated with $\mathrm{HBs}$ antigen (HBsAg). Anti-HBs secreting spleen cells were induced as well by the injection of the anti-Id alone without antigen. ${ }^{1}$ These findings suggest that the immune response to anti-HBs, at least in mice, is regulated through an Id-anti-Id network.

Studies were undertaken to evaluate whether this system of immunoregulatory control is operative in man. In vitro culture of human peripheral blood lymphocytes stimulated with anti-anti-HBs or purified HBsAg in the presence of pokeweed mitogen was used.

Address for correspondence: Dr Shinichi Kakumu. Third Department of Medicine, Nagoya University School of Medicine. 65 Tsuruma-cho, Showaku, Nagoya 466, Japan.

Received for publication 29 November 1985

\section{Methods}

PATIENTS

We studied four patients positive for serum antiHBs, three chronic HBsAg carriers and three control individuals. All patients with anti-HBs and chronic carriers showed features of chronic persistent hepatitis or minor, non-specific changes in liver histology. The three controls were all negative for HBsAg and anti-HBs serology. A preliminary study showed that peripheral blood lymphocytes from all four patients positive for anti-HBs secreted detectable amounts of anti-HBs into culture medium when cultured with pokeweed mitogen.

\section{SEPARATION OF LYMPHOCYTES}

Peripheral blood mononuclear cells were isolated from heparinised venous blood by Ficoll-Hypaque gradient sedimentation. The interphase peripheral blood mononuclear cells were suspended at $2.5 \times 10^{6}$ cells/ml in RPMI 1640 (GIBCO) culture medium (RPMI 1640 supplemented with $15 \%$ heat inactivated fetal bovine serum, glutamine and antibiotics).

\section{ADDITIVES}

The HBsAg (serotype adr) prepared from pooled human plasma was kindly provided by Dr Takashi Takahashi of Kitasato Institute, Tokyo, Japan. 
Purification was carried out by sequential density gradient separations using zonal centrifugation procedures. $^{\times}$

Monoclonal antibody against the above HBsAg obtained from ascitic mice ${ }^{9}$ was kindly supplied by Dr Namiko Yoshihara, National Institute of Health, Tokyo, Japan. IgG proteins of ascitic fluids were obtained from saturated $\left(\mathrm{NH}_{4}\right)_{2} \mathrm{SO}_{4}$ precipitates and by subsequent DEAE-cellulose column chromatography.

$\mathrm{F}\left(\mathrm{ab}^{\prime}\right)_{2}$ and $\mathrm{Fc}$ fragments of $\mathrm{IgG}$ were isolated by pepsin digestion and isolated by Sephadex G150 gel chromatography. $F\left(a^{\prime}\right)$ fragments $(1 \mathrm{mg})$ were injected into rabbits weighing approximately $2 \mathrm{~kg}$ together with complete Freund's adjuvant. After 14 days, two booster injections of the $F\left(a b^{\prime}\right)_{2}$ fragments $(0.5 \mathrm{mg})$ in complete Freund's adjuvant were given at weekly intervals. Rabbits were bled and killed 10 days after the last booster injection. Rabbits antiserum was extensively absorbed with mouse Ig. Aliquots of antiserum were passed through five times on a $\mathrm{CNBr}$-activated Sepharose 4B column coupled with normal mouse serum IgG. The isolation of $\operatorname{IgG}$ and preparation of $F\left(a b^{\prime}\right)_{2}$ of affinitypurified antiserum were carried out as described above. Antibody against monoclonal antibody (6D6) to human liver specific membrane lipoprotein (LSP) was raised in rabbits using an identical procedure as the above, ${ }^{10}$ and served as a control. An IgG fraction obtained from rabbit antiserum to normal mouse serum was also provided as a control. We determined the antibody concentration in a spectrophotometer at $280 \mathrm{~nm}$ using an extinction coefficiency of 15 for a $1 \%$ preparation.

CELL CUITURE CONDITIONS

Peripheral blood mononuclear cells $\left(2 \times 10^{6} / \mathrm{ml}\right)$ were cultured in a $1.0 \mathrm{ml}$-final volume RPMI 1640 culture medium in the presence of HBsAg ( $100 \mathrm{ng}-$ $1 \mu \mathrm{g} / \mathrm{ml})$ or anti-anti-HBs $(20-200 \mathrm{ng} / \mathrm{ml})$ with $20 \mu \mathrm{g}$ pokeweed mitogen in $12 \times 75 \mathrm{~mm}$ culture tubes. The cells were cultured at $37^{\circ} \mathrm{C}$ in a moist atmosphere of $5 \% \mathrm{CO}_{2}$. The cells were then washed extensively to remove the additives and cultured in $1 \mathrm{ml}$ culture medium without any additives for another seven days at $37^{\circ} \mathrm{C}$ in a $5 \% \quad \mathrm{CO}_{2}$ atmosphere. At the termination of the culture period, the cells were centrifuged and the culture supernatants were stored at $-20^{\circ} \mathrm{C}$.

HEPATITIS B VIRUS SEROLOGIC TESTING HBsAg, anti-HBs, anti-HBc, HBe antigen and anti-HBe were determined using commercially available radioimmunoassay kits (Abbott).

IMMUNOGLOBULIN MEASUREMENTS

Total IgG and IgM concentrations in culture super- natants were measured with a microtitre plate enzyme linked immunoassay (ELISA). ${ }^{11} 12$ Microplates (Dynatec) were coated with $100 \mu \mathrm{l}$ of $10 \mu \mathrm{g} / \mathrm{ml}$ rabbit anti-human IgG or IgM (Cappel Lab.) in carbonate buffer ( $\mathrm{pH} \mathrm{9.6)} \mathrm{to} \mathrm{each} \mathrm{well.} \mathrm{The} \mathrm{plates}$ were incubated overnight at $4^{\circ} \mathrm{C}$ and then washed with $0.05 \%$ Tween-20 in phosphate buffered saline

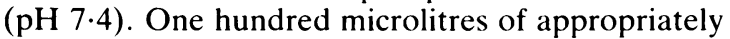
diluted test samples and standard human $\mathrm{IgG}$ or IgM were added in duplicate and incubated for three hours at $4^{\circ} \mathrm{C}$. After washing, $100 \mu \mathrm{l}$ rabbit-human IgG- or IgM-conjugated peroxidase (Cappel Lab.) were added to each well and incubated for two hours at room temperature. The enzyme reaction was undertaken with orthophenylene-diamine dissolved in substrate buffer $\left(\mathrm{pH} \mathrm{5.0)}\right.$ and $33 \% \mathrm{H}_{2} \mathrm{O}_{2}$. Light absorbance was measured at $492 \mathrm{mn}$ in a spectrophotometer. Absorbance by wells of test samples was expressed as nanograms of IgG or IgM by reference to a standard curve constructed by linear regression analysis. Standard curves were linear in the range of 5 to $80 \mathrm{ng} / \mathrm{ml}$.

STATISTICAL ANALYSIS

The significance of differences between groups were determined by Student's $t$ test.

\section{Results}

Peripheral blood mononuclear cells from four patients positive for anti-HBs released significantly increased amounts of anti-HBs into culture medium when purified HBsAg or IgG fraction of anti-antiHBs was added as compared with the anti-HBs levels in culture with pokeweed mitogen alone (Table 1). The enhancement of anti-HBs production occurred in a dose dependent manner and the similar amounts of anti-HBs were produced in the presence of HBsAg and anti-anti-HBs. These additives alone, however, did not induce the production of detectable amounts of anti-HBs in cultures. The addition of $\mathrm{HBsAg}$ or anti-anti-HBs did not affect the levels of anti-HBc, IgG and IgM.

Peripheral blood mononuclear cells from three chronic HBsAg carriers and three control individuals did not produce detectable amounts of anti-HBs although similar amounts of $\mathrm{IgG}$ were found in the presence of HBsAg or anti-anti-HBs together with pokeweed mitogen (data not shown).

In another set of experiments, we examined the effect of IgG fragments of anti-anti-HBs on antiHBs production in cultures by peripheral blood mononuclear cells. The peripheral blood mononuclear cells from three patients with anti-HBs showed significantly enhanced anti-HBs production on the addition of $F\left(a b^{\prime}\right)_{2}$ fragments (radioimmunoassay 
Table Effects of anti-anti-HBs or HBsAg on the productions of anti-HBs, anti-HBc and immunoglobulins by PWM stimulated human peripheral blood mononuclear cells (PBMC)

\begin{tabular}{|c|c|c|c|c|}
\hline Additives $(\mu \mathrm{g} / \mathrm{ml})$ & $\begin{array}{l}\text { Anti-HBs } \\
\text { (RIA ratio) }\end{array}$ & 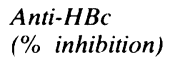 & $\lg G(n g / m l)$ & $\lg M(n g / m l)$ \\
\hline PWM alone $(20)$ & $5 \cdot 2 \pm 2 \cdot 0$ & $23 \cdot 2 \pm 4 \cdot 3$ & $18750 \pm 11153$ & $5130 \pm 1771$ \\
\hline \multirow{3}{*}{ PWM+anti-anti-HBs } & $19 \cdot 5 \pm 6.9 \dagger$ & $24 \cdot 0 \pm 12 \cdot 9$ & $20766 \pm 11465$ & $4940 \pm 1362$ \\
\hline & $23 \cdot 9 \pm 8 \cdot 7 \dagger$ & $23 \cdot 2 \pm 7 \cdot 9$ & $21787 \pm 12894$ & $4927 \pm 1334$ \\
\hline & $13 \cdot 6 \pm 5 \cdot 7^{*}$ & $23 \cdot 9 \pm 7 \cdot 0$ & $20000 \pm 11100$ & $5147 \pm 1619$ \\
\hline PWM+HBsAg (1) & $13 \cdot 9 \pm 6 \cdot 6^{*}$ & $20 \cdot 7 \pm 12 \cdot 5$ & $18850 \pm 10061$ & $5147 \pm 1114$ \\
\hline$(0 \cdot 4)$ & $24 \cdot 6 \pm 10 \cdot 2 \dagger$ & $22 \cdot 6 \pm 8 \cdot 1$ & $21550 \pm 11050$ & $4697 \pm 1408$ \\
\hline$(0 \cdot 1)$ & $18 \cdot 8 \pm 5 \cdot 7 \dagger$ & $25 \cdot 1 \pm 9 \cdot 4$ & $20533 \pm 11656$ & $5090 \pm 1526$ \\
\hline
\end{tabular}

Peripheral blood mononuclear cells from four patients positive for serum anti-HBs were cultured with IgG fraction of anti-anti-HBs or purified HBsAg in the presence of pokeweed mitogen for three days. After extensive washing, the cells were cultured without any additives for another seven days. After the culture, the supernatants were obtained. Results were expressed as mean \pm SD from four different experiments. ${ }^{*}: p<0 \cdot 05, \dagger: p<0 \cdot 01$.

ratio $=21 \cdot 7 \pm 6 \cdot 3$, mean $\pm \mathrm{SD}, \mathrm{p}<0 \cdot 05$ ) or the $\mathrm{IgG}$ fraction $(16 \cdot 7 \pm 5 \cdot 5, \mathrm{p}<0 \cdot 05)$ when compared with the cultures in pokeweed mitogen alone $(4 \cdot 3 \pm 1 \cdot 4)$ (Figure). On the other hand, anti-HBs levels in the presence of $\mathrm{Fc}$ fragments did not differ from those of pokeweed mitogen alone. The addition of an acid elution fraction of anti-anti-HBs antiserum from affinity column coupled to serum IgG of normal mouse did not affect anti-HBs production by peripheral blood mononuclear cells.

Anti-HBs production by peripheral blood mononuclear cells was not increased or decreased in the presence of IgG fraction of anti-anti-LSP monoclonal antibody or antiserum to normal mouse serum used as control additives (data not shown).

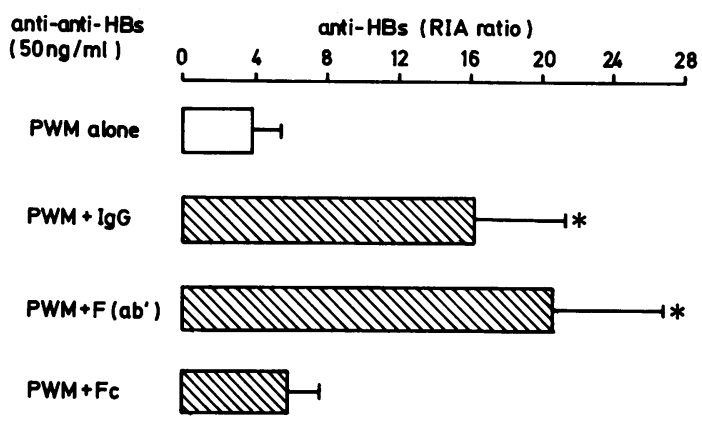

Figure Studies were undertaken to determine which fragments of $\operatorname{IgG}$ of anti-anti-HBs could modulate anti-HBs production. Peripheral blood mononuclear cells (PBMC) from three patients positive for serum anti-HBs were cultured with fixed amounts $(50 \mathrm{ng} / \mathrm{ml})$ of $\mathrm{F}\left(a b^{\prime}\right)_{2}$ or Fc fragments of anti-anti-HBs in the presence of pokeweed mitogen $(P W M)$. Results were expressed as mean $\pm S D .{ }^{*}: p<0.05$.

\section{Discussion}

In the present study we have shown that anti-antiHBs as well as HBsAg generates an enhanced anti-HBs response in cultures in the presence of pokeweed mitogen when peripheral blood mononuclear cells from patients positive for serum anti-HBs are used as effector cells. The specificity of anti-anti-HBs for enhanced anti-HBs production was indicated by the following: anti-anti-HBs antiserum was obtained by immunisation with $F\left(a^{\prime}\right)_{2}$ fragments of anti-HB, an anti-HBs response was increased by $F\left(a b^{\prime}\right)_{2}$ fragments of anti-anti-HBs but not by $\mathrm{Fc}$ fragments or acid elution of anti-anti-HBs from affinity column coupled to normal mouse IgG, anti-HBs production was not affected by rabbit antiserum to unrelated control antibodies. These findings suggest that an immunomodulatory control by anti-Id to Id of anti-HBs is also operative in man as others have already shown in mice. ${ }^{67}$

If the paratope and Id represent the same structural region on the antibody molecule, then the conformational fit of the antigen and anti-Id to the sites on the antibody should be similar though a mirror image ${ }^{13}$ It should be possible to utilise the anti-Id for antigen mimicry and trigger the host's immune response into producing antibody by administering anti-Id.

We used rabbit anti-anti-HBs antiserum generated against anti-HBs monoclonal antibody raised in mice. A common Id was defined by a rabbit anti-Id antiserum generated against human anti-HBs. ${ }^{14}$ This common Id associated with anti-HBs was also identified in sera from rabbits, mice, guinea pigs, swine, goats, and chimpanzees that had been immunised with $\mathrm{HBsAg} .{ }^{15}$ It is possible therefore that rabbit anti-anti-HBs antiserum induces an 
enhanced anti-HBs response by human peripheral blood mononuclear cells. In addition, the anti-Idinduced anti-HBs recognised the group-specific a determinant of $\mathrm{HBsAg}$ that is responsible for inducing protective immunity against $\mathrm{HB}$ virus, suggesting the potential for the use of anti-Id vaccines for $\mathrm{HB}$ virus infections. ${ }^{7}$ Such success has been reported with anti-Id-induced protection in experimental trypanosomiasis. ${ }^{16}$ It is indicated, however, that this anti-Id-induced protective effect is genetically restricted. ${ }^{17}$ This is important because man represents a genetically outbred population, which may severely limit the effectiveness of anti-Id vaccines. The problems associated with using idiotype antibodies produced in a heterologous species for injection into humans may be circumvented by the use of human hybridoma antibodies.

Although we have shown that the immune response to $\mathrm{HBs} \mathrm{Ag}$ in man is regulated through an Id-anti-Id network, whether the regulation of this compartment of the immune system plays any role in determining the outcome of $\mathrm{HB}$ virus infection remains to be confirmed.

\section{References}

1 Jerne NK. Towards a network theory of the immune system. Ann Immunol 1974; 125C: 373-89.

2 Cosenza H, Köhler $H$. Specific suppression of the antibody response by antibodies to receptors. Proc Natl Acad Sci USA 1972; 69: 2701-5.

3 Eichman K. Idiotype suppression. I. Influence of the dose and of the effector functions of anti-idiotypic antibody on the production of an idiotype. Eur $J$ Immunol 1974; 4: 296-302.

4 Cazenave PA. Idiotypic-anti-idiotypic regulation of antibody synthesis in rabbits. Proc Natl Acad Sci USA 1977; 74: 5122-5.

5 Bluestone JA, Sharrow SO, Epstein SL, Ozato K, Sachs DH. Induction of anti-H-2 antibodies without alloantigen exposure by in vivo administration of antiidiotype. Nature 1981; 291: 233-5.
6 Kennedy RC, Adler-Storthz K, Henkel RD, Sanchez Y, Melnick JL, Dreesman GR. Immune response to hepatitis B surface antigen: enhancement by prior injection of antibodies to the idiotype. Science 1983; 221: 853-5.

7 Kennedy RC, Melnick JL, Dreesman GR. Antibody to hepatitis $\mathrm{B}$ virus induced by injecting antibodies to the idiotype. Science 1984; 223: 930-1.

8 Takahashi T, Saito $\mathrm{H}$, Kurokawa M, Yasuda J, Hashimoto T. Studies on the potency test of HB vaccine by the parallel line assay method in guinea pigs. Jpn J Med Sci Biol 1982; 35: 53-62.

9 Wands JR, Zurawski VR Jr. High affinity monoclonal antibodies to hepatitis $\mathrm{B}$ surface antigen (HBsAg) produced by somatic cell hybrids. Gastroenterology 1981; 80: 225-32.

10 Murakami H, Kuriki J, Kakumu S, Fukui K, Sakamoto $\mathrm{N}$. The specificity of human liver membrane lipoprotein: studies with monoclonal antibodies. Hepatology 1984; 4: 192-8.

11 Franz J, Corthier G. Measurement of porcine faecal IgA, IgG and IgM levels by a competitive enzymelinked immunosorbent assay. Clin Exp Immunol 1981; 44: 645-9.

12 Lems-Van Kan P, Verspaget HW, Pena AS. ELISA assay for quantitative measurement of human immunoglobulins $\operatorname{IgA}$, IgG and IgM in nanograms. $J$ Immunol Methods 1983; 57: 51-7.

13 Dreesman GR, Kennedy RC. Anti-idiotypic antibodies: implications of internal image-based vaccines for infectious diseases. $J$ Infect Dis 1985; 151: 761-5.

14 Kennedy RC, Dreesman GR. Common idiotypic determinant associated with human antibodies to hepatitis B surface antigen. J Immunol 1983; 130: 385-9.

15 Kennedy RC, Ionescu-Matin I, Sanchez Y, Dreesman RC. Detection of interspecies idiotypic cross-reactions associated with antibodies to hepatitis B surface antigen. Eur J Immunol 1983; 13: 232-5.

16 Sacks DL, Esser KM, Sher A. Immunization of mice against African trypanosomiasis using anti-idiotypic antibodies. J Exp Med 1982; 155: 1108-19.

17 Sacks DL, Sher A. Evidence that anti-idiotype induced immunity to experimental African trypanosoniasis is genetically restricted and requires recognition of combining sited-related idiotypes. I Immunol 1983; 131: 1511-5. 